\title{
INFLUENCE OF LANDSCAPE STRUCTURE ON THE FUNCTIONAL GROUPS OF AN APHIDOPHAGOUS GUILD: ACTIVE-SEARCHING PREDATORS, FURTIVE PREDATORS AND PARASITOIDS
}

\author{
JULIE-ÉLÉONORE MAISONHAUTE* AND ÉRIC LUCAS
}

Laboratoire de lutte biologique, Département des sciences biologiques, Université du Québec à Montréal, C.P. 8888, Succ. Centre ville, Montréal (Québec) H3C 3P8 CANADA, Tel (514) 987-3000 (4799\#) Fax: (514) 987-4647

${ }^{*}$ Corresponding author: jemaisonhaute@ymail.com

\section{ABSTRACT}

A lot of studies focusing on the effect of agricultural landscapes demonstrate that many arthropod species are influenced by landscape structure. In particular, non-crop areas and landscape diversity are often associated with a higher abundance and diversity of natural enemies in fields. Numerous studies focused on the influence of landscape structure on ground beetles, spiders and ladybeetles but few on other natural enemies or different functional groups. Thus, the objective of the present study was to determine the influence of landscape structure on the functional groups, i.e., active-searching predators, furtive predators and parasitoids of aphidophagous guilds. Natural enemies were sampled on milkweed infested with aphids, growing along the borders of ditches adjacent to cornfields. The sampling occurred weekly from June to September in 2006 and 2007, in the region of Lanaudière (Quebec, Canada). The landscapes within a radius 200 and $500 \mathrm{~m}$ around each site were analyzed. The abundance, richness and species composition (based on functional groups) of natural enemies were related to landscape structure. The results indicated that landscape structure explained up to $21.6 \%$ of the variation in natural enemy assemblage and confirm the positive effects of non-crop areas and landscape diversity. A lower influence of landscape structure on species composition was observed (6.4 to $8.8 \%$ ) and varied greatly among the functional groups. Coccinellidae and furtive predators were the group most influenced by landscape structure. In conclusion, the influence of landscape varied greatly among the different species of the same functional group.

Keywords: Aphidophagous predators, Cecidomyiidae, Coccinellidae, landscape diversity, milkweed, non-crop areas

\section{Introduction}

The aphidophagous guilds are composed of an array of different species that may control aphids in the field. Recently, Ramirez and Snyder (2009) showed that functional diversity rather than taxonomic diversity may be the key factor for improving the natural control of pests. Aphidophagous species can be divided into several functional groups: active-searching predators (e.g., ladybeetles), furtive predators (e.g., chamaemyiid larvae), parasitoids (e.g., parasitoid wasps) and pathogens (e.g., virus, bacteria, fungus). Active-searching predators, such as ladybeetles (Coleoptera: Coccinellidae), lacewing larvae (Neuroptera: Chrysopidae and Hemerobiidae) and hoverfly larvae (Diptera: Syrphidae), do not necessarily live within or close to aphid colonies and search actively for their prey. Their hunting behaviour is composed of extensive and intensive search (Ferran and Dixon 1993) and usually induces a strong defensive response from aphids, such as walking, dropping or swiveling (Dixon 1958; Losey and Denno 1998). Active-searching predators detect their prey by direct contact, which is the case for Coccinellidae (Frazer 1988) and Syrphidae (Chambers 1988). However, Coccinellidae can also detect their prey using olfactory and visual cues (Obata 1986; Harmon et al. 1998). Coccinellidae are voracious predators that actively search for prey, specifically along the edges of leaves or by following surface irregularities (veins), where aphids are most likely to occur (Dixon 1959; Marks 1977). Finally, they may engage in intraguild predation on other actively searching or furtive predators, or on aphids infested by pathogens or parasitized (Lucas 2005). Conversely, furtive predators, including Cecidomyiidae and Chamaemyiidae larvae (Diptera) are predators that live close by or within aphid colonies, whose hunting behaviour is characterized by slow and creeping movements, which do not induce a significant defensive response from aphids (Lucas and Brodeur 2001; Frechette et al. 2008). For instance, the furtive predator, Aphidoletes aphidimyza (Rondani), which is a specialist predator of aphids, lives in or close to aphid colonies because of its low capacity of movement $(63 \mathrm{~mm}$ linear without feeding for neonate individuals) (Markkula and Tiittanen 1985). Furtive predators are tiny, vermiform specialists with low voracity. They have a close relation to their prey, as females of A. aphidimyza increase the number of eggs laid with high aphid densities (Lucas and Brodeur 1999). Finally, aphid parasitoids include parasitoid wasps belonging to various families of Hymenoptera (e.g., Braconidae, Aphelinidae) that can be either host specific or more generalist parasitoids. Aphid parasitoids detect aphids, their host plant (Vet et al. 1991) or suitable habitats using chemical cues (Vinson 1998). For instance, the milkweed aphid is parasitized by Lysiphlebus testaceipes (Cresson) (Hymenoptera: Braconidae, Aphidiinae), a generalist koinobiont endoparasitoid whose parasitism rate depends on aphid density (Helms et al. 2004). Overall, active-searching predators, furtive predators and aphid parasitoids can be used to control aphids in fields. 
Another way to improve aphid biocontrol in fields is to use conservative biological control. The conservative biocontrol approach is based on a "modification of the environment or existing practices to protect and enhance specific natural enemies or other organisms to reduce the effect of pests" (Eilenberg et al. 2001). In particular, the objective of the manipulation of the environment is to "enhance the survival, fecundity, longevity and behaviour of natural enemies to increase their effectiveness" (Landis et al. 2000). Thus, conservative biocontrol is closely related to the management of the agricultural landscape. That landscape structure affects arthropods is now widely accepted and recorded for various groups. Indeed, landscape structure is known to affect the whole arthropod community (Schweiger et al. 2005) or specific groups, like ground beetles (Coleoptera: Carabidae) (Weibull and Östman 2003; Maisonhaute et al. 2010), spiders (Araneae) (Thorbek and Topping 2005) and ladybeetles (Gardiner et al. 2009a). There are few studies on the influence of landscape structure on other organisms, such as parasitoids (Marino et al., 2006), Syrphidae (Sarthou et al. 2005), Chrysopidae and Hemerobiidae (Mignon et al. 2003) and no study on Cecidomyiidae and Chamaemyiidae. Interestingly, specialist natural enemies of aphids (i.e., parasitoids and cecidomyiid larvae) are more abundant in complex landscapes (i.e., landscape with a high percentage of perennial habitat) with more aphids, whereas generalists (ladybeetles and spiders) are more abundant in simple landscapes where there are fewer aphids (Rand and Tscharntke 2007). Finally, there are no studies comparing the effect of landscape structure on the functional groups of aphidophagous guilds (active-searching predators, furtive predators, parasitoids).

Among the landscape descriptors studied, non-crop areas are important components of agricultural landscape because they represent nutritional resources, provide shelters for overwintering and places for natural enemies to reproduce (Landis et al. 2000). For example, field margins can provide floral resources for many aphidophagous natural enemies, specifically parasitoids (Lee et al. 2006) and active-searching predators like hoverflies (Cowgill et al. 1993). Field margins may also provide floral resources for Coccinellidae (Hagen 1962) and Chrysopidae (New 1988) because they feed on pollen and nectar. Consequently, it is not surprising that non-crop areas often support a high abundance and diversity of parasitoids (Roschewitz et al. 2005) and active-searching predators, especially ladybeetles (Burgio et al. 2004; Burgio et al. 2006). Moreover, a high proportion of non-crop areas in an agricultural landscape is associated with an increase in the abundance and diversity of coccinellids in fields (Elliott et al. 1998; Elliott et al. 2002a; Gardiner et al. $2009 \mathrm{~b}$ ) and in the percentage of aphids parasitized (Roschewitz et al. 2005; Thies et al. 2005). Landscape diversity is also an important parameter positively associated with the abundance of Coccinellidae and the biological control of aphids (Gardiner et al. 2009a,b). Other stud- ies have found that the species assemblage and relative abundance of different Coccinellidae species are influenced by landscape complexity, which takes into account both landscape diversity and the proportion of non-crop areas (ColungaGarcia et al. 1997). The abundance of Coccinellidae is also affected by landscape fragmentation but the effects depend on the species considered and are non consistent among the studies (Grez et al. 2004; Zaviezo et al. 2006). Finally, the abundance of Coccinellidae can be influenced by the shape of landscape elements (Square patch versus I patch), since their migration from the focal field increases with the area to perimeter ratio (Grez and Prado 2000). In summary, most of the studies on the influence of landscape structure were performed on Coccinellidae, and few on other active-searching predators. In fact, Syrphidae are positively influenced by the presence of flowers (Sutherland et al. 2001; Sarthou et al. 2005), woodland geometry and the area of shrubby fallows (Sarthou et al. 2005). Regarding lacewings, Chrysopidae are less abundant in fields adjacent to woodland but this is not the case for Hemerobiidae (Mignon et al. 2003). Finally, regarding the furtive predators, there appears to be no study on the effect of landscape structure on cecidomyiid or chamaemyiid larvae.

As there are only a few studies on the effect of landscape structure on aphidophagous natural enemies other than Coccinellidae, it is difficult to compare the different functional groups. Thus, the objective of the present study was to compare the effect of landscape structure on the different functional groups of aphidophagous guilds found in non-crop areas and more specifically to identify which landscape descriptors influence each functional group.

\section{Material and Methods}

\section{Sampling}

The sampling area was the Vacher creek watershed (Lanaudière, Quebec, Canada), which covers $69 \mathrm{~km}^{2}$ and includes the town of Saint-Jacques $\left(45^{\circ} 56^{\prime} \mathrm{N}, 73^{\circ} 34^{\prime} \mathrm{O}\right)$ and Sainte-Marie-Salomé $\left(45^{\circ} 55^{\prime} \mathrm{N}, 73^{\circ} 29^{\prime} \mathrm{O}\right)$. This area was chosen because 1) it was previously studied as part of a bigger project on the effects of landscape structure in intensive agricultural landscapes and 2) landscapes with different land use configurations are found in the watershed (Ruiz et al. 2008). Nineteen sites were sampled, distributed throughout the entire watershed, during the summers of 2006 and 2007. Each site was a ditch border adjacent to a cornfield. Natural enemies were sampled on common milkweed, Asclepias syriaca L. (Asclepiadaceae), infested with aphids (Aphis nerii Boyer de Fonscolombe and Aphis asclepiadis Fitch in 2006 and also Myzocallis asclepiadis (Monell) in 2007). In 2006, up to four milkweed plants per site were sampled each week. Because only a few natural enemies were observed in 
2006, it was decided to increase the number of milkweed plants sampled per site in 2007 in order to increase the chance of observing natural enemies. Consequently, up to five milkweed plants per site were sampled weekly in 2007. In both years, the same milkweed plants infested with aphids were sampled each week until the aphids disappeared, when another milkweed plant infested with aphids was chosen so that the recording of natural enemies could continue.

\section{Landscape analysis}

Orthophotos dating from 1998 and data on land-use were obtained from the Ministère du Développement durable, de l'Environnement et des Parcs du Québec. Landscape data were updated using information gathered from the field in 2006 and 2007, especially that on the nature of the crops around each site. Landscape cartography was performed at 2 scales, i.e., within a radius of $200 \mathrm{~m}$ and $500 \mathrm{~m}$ around each site. Because fields are often larger than $200 \mathrm{~m}$, analyses on scales smaller than $200 \mathrm{~m}$ would not be interesting (almost only cornfields would have been observed). Analyses on larger scales than $500 \mathrm{~m}$ have not been performed because of logistic constraints (the nature of crop fields was based on field observations and it would have taken too much time to determine the exact landscape composition on a scale larger than $500 \mathrm{~m}$ ). Landscape structure was evaluated by landscape composition (area under different landscape elements and landscape diversity) and landscape configuration (spatial arrangement of the landscape elements), see Table 1. At both scales, landscape composition was evaluated by the area of different landscape elements: corn, other crops (soybean, cereal, potato, vegetables and berries), fodder crop, pasture, woodland, other non-crop areas (riparian vegetation and fallow), water and built on areas. Landscape diversity at both scales was assessed using the Shannon index of diversity (Yoshida and Tanaka 2005), which takes into account the number and proportion of different landscape elements. Descriptors of landscape configuration at both scales included the density of field borders (length of field borders per unit area), patchiness (number of patches of landscape elements) and non-crop area patchiness (number of non-crop patches). One more descriptor was added to the $500 \mathrm{~m}$ matrix: the mean field area. This descriptor was added to the $500 \mathrm{~m}$ matrix only because the field area overlapped $200 \mathrm{~m}$ at almost all the sites. Overall, 12 variables were included in the $200 \mathrm{~m}$ matrix and 13 in the $500 \mathrm{~m}$ matrix.

\section{Statistical analysis}

The influence of landscape structure was evaluated on the abundance, richness and the species composition of natural enemies observed during the entire season. Milkweed is a small plant so natural enemies can easily be observed on the whole plant. Because milkweed plant infested with aphids represents the sampling unit, data were pooled for each plant. Natural enemy abundance corresponded to the mean abundance of natural enemies observed per plant during the entire season and data were square root transformed. Natural enemy richness corresponded to the mean number of species observed per plant during the entire season. In the species composition matrix, the functional groups were distinguished and included active predators (Coccinellidae, Chrysopidae, Hemerobiidae and Syrphidae), furtive predators (Cecidomyiidae and Chamaemyiidae) and parasitoids. Then, because coccinellid species can respond differently

Table 1 Landscape descriptors included in the analyses of the 200 and $500 \mathrm{~m}$ data sets. The $200 \mathrm{~m}$ landscape matrix included 12 landscape descriptors and the $500 \mathrm{~m}$ landscape matrix 13.

aThe Shannon index of diversity was calculated using 13 land-use categories: corn, soybean, cereal, other crops, fodder crop, pasture, woodland, fallow, riparian vegetation, water, built on area, road, sand pit b500 m only

\begin{tabular}{|l|l|c|}
\hline Landscape descriptors at 200 and 500m & \multicolumn{1}{|c|}{ Description } & Unit \\
\hline Corn & Area under corn & $\mathrm{m}^{2}$ \\
\hline Other crops & Area under crops other than corn (soybean, cereal, potato, vegetable, berry) & $\mathrm{m}^{2}$ \\
\hline Fodder crop & Area under fodder crops & $\mathrm{m}^{2}$ \\
\hline Pasture & Area under pasture & $\mathrm{m}^{2}$ \\
\hline Woodland & Area under woodland & $\mathrm{m}^{2}$ \\
\hline Other non-crop areas & Area under fallow and riparian vegetation & $\mathrm{m}^{2}$ \\
\hline Water & Area under water (creek, river and natural pools) & $\mathrm{m}^{2}$ \\
\hline Built on areas & Area covered by houses and other buildings & $\mathrm{m}^{2}$ \\
\hline Landscape diversity & $\mathrm{m}^{2}$ \\
\hline Density of field borders & Shannon index & $\mathrm{m} \mathrm{ha}^{-1}$ \\
\hline Patchiness & Length of field borders per unit area & - \\
\hline Non-crop patchiness & Number of patches of landscape elements & - \\
\hline Field area ${ }^{b}$ & Number of non-crop patches & $\mathrm{m}^{2}$ \\
\hline
\end{tabular}


to landscape structure, the different species and the most abundant were integrated individually into the matrix (4 species). Overall, the species composition matrix included the mean abundance of 7 groups of natural enemies, taking into account the relative abundance of each group: Coleomegilla maculata lengi Timberlake, Harmonia axyridis (Pallas), Propylea quatuordecimpunctata $\mathrm{L}$. and Coccinella septempunctata L., other active predators (Chrysopidae, Hemerobiidae and Syrphidae), furtive predators and parasitoids. Data in the species composition matrix were transformed using a Hellinger transformation (Legendre and Gallagher 2001).

Statistical analyses were based on a redundancy analysis (Legendre and Legendre 1998) followed by a variation partitioning scheme (Borcard et al. 1992; Peres-Neto et al. 2006) using MATLAB $^{\circ}$ (MathWorks 2000). Each year, 3 different analyses were performed to evaluate the effect of landscape structure on the different response matrices: 1) natural enemy abundance, 2) richness and 3) species composition throughout the entire season. The explicative matrices corresponded to the landscape matrix at $200 \mathrm{~m}$ and $500 \mathrm{~m}$. The procedure was the same for all the analyses. First, in each set of landscape descriptors (i.e., the $200 \mathrm{~m}$ and $500 \mathrm{~m}$ matrix) the variables that had a significant influence on the response matrix were selected. Forward selection was used to select the variables (permutation test with 999 permutations, $\alpha=0.005$ ). Then, a variation partitioning scheme was applied with the selected variables within each set to determine the contribution of landscape descriptors at $200 \mathrm{~m}$ and at $500 \mathrm{~m}$ in accounting for the differences in the response matrix. The variation partitioning between two matrices is illustrated in Fig. 1, with $\mathrm{X} 1$ and $\mathrm{X} 2$ representing the global effect of landscape structure, respectively, at $200 \mathrm{~m}$ and $500 \mathrm{~m}$. Since the contribution shared between the 2 matrices can be negative, the global effect of landscape structure (i.e., including the effect at 200 and $500 \mathrm{~m}$ ) can be smaller than that recorded when each matrix is considered individually. Finally, regression slopes were calculated for each significant variable in order to determine the force and direction of its influence. A positive slope indicates a positive influence and a negative slope a negative influence. A greater slope is associated with a higher influence of the descriptor.

\section{Results}

\section{Natural enemy abundance and richness}

In 2006, 7 sites were not included in the analyses because of the absence of natural enemies on milkweed infested with aphids. At the other sites (12 sites), a total of 177 natural enemies were observed on 31 milkweed plants infested with aphids (A. nerii or A. asclepiadis). The natural enemies observed belonged to the Coccinellidae (C. maculata, $H$. axyridis, P. quatuordecimpunctata and C. septempunctata), Chrysopidae, Hemerobiidae, Syrphidae Cecidomyiidae and parasitoids. No Chamaemyiidae was observed during the 2 years. Some coccinellid larvae were also observed but not identified to species, so were included in the analysis of natural enemy abundance but not in that of the species composition. The mean abundance of natural enemies per plant throughout the entire season was $1.47 \pm 2.98$ (mean \pm standard deviation), varying from 0.14 to17.00 natural enemies per plant. The mean richness per plant was $1.87 \pm 1.15$ and varied from 1 to 5 species. The most abundant natural enemies were cecidomyiid larvae (36.72\% of the total), followed by $H$. axyridis (27.68\%), unidentified coccinellid larvae (11.30\%), Syrphid larvae (7.91\%), C. maculata (6.78\%), P. quatuordecimpunctata (3.95\%) and other groups accounted for less than $3 \%$ each.

In 2007, one site was not included in the analyses because no natural enemies were recorded there on milkweed infested with aphids. At the 18 other sites, a total of 282 natural enemies were observed on 148 milkweed plants infested with aphids (A. nerii, A. asclepiadis or $M$. asclepiadis). The natural enemies were similar to those observed in 2006 except for 2 coccinellids, which were observed only in 2007: Brachiacantha ursina (Fabricius) and Hippodamia convergens Guérin-Meneville. These two species were included in the abundance and richness analyses but not in the analyses of the species composition because too few specimens were observed. The mean abundance of natural enemies per plant throughout the entire season was $1.22 \pm 0.66$ (mean \pm standard deviation), varying from 0.17 to 5 natural enemies per plant. The mean richness per plant was $1.33 \pm 0.69$ and varied from 1 to 6 species. The most abundant natural

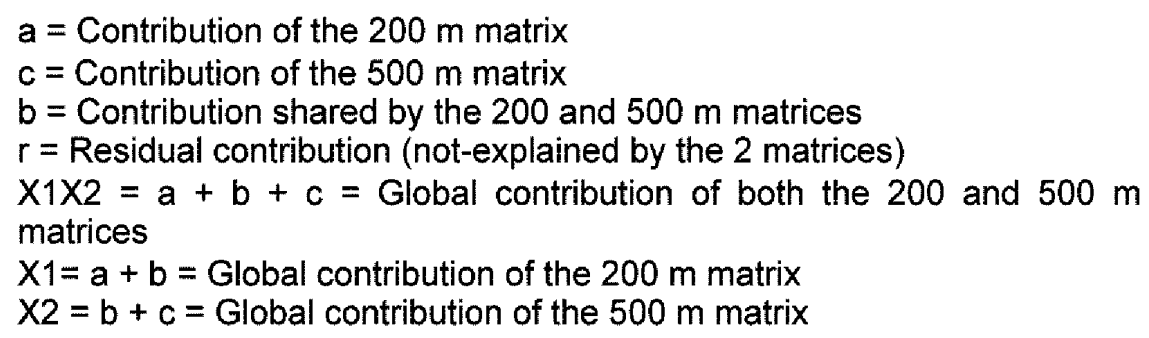

Fig. 1 Variation partitioning between landscape descriptors at 200 and $500 \mathrm{~m}$. The continuous circle represents the global association with landscape structure at $200 \mathrm{~m}$ (X1) and the dotted circle that at $500 \mathrm{~m}$ (X2). 
enemies were P. quatuordecimpunctata (23.05\%), C. maculata (22.34\%), H. axyridis (19.15\%), C. septempunctata (17.73\%), cecidomyiid larvae $(8.51 \%)$, unidentified coccinellid larvae $(4.26 \%)$ and the other groups accounted for less than $2 \%$ each.

\section{Influence of landscape structure}

In 2006, crop-areas (excluding fodder crop) within $500 \mathrm{~m}$ around each site occupied between 23.75 and $79.46 \%$ of the superficies. Cornfields accounted for from 4.81 to $55.35 \%$. Non-crop areas (including fallow, pasture, riparian vegetation and woodland) occupied between 0 and $54.27 \%$ of the superficies and landscape diversity estimated using the Shannon index of diversity varied from 1.35 to 2.28. In 2007, crop-areas within $500 \mathrm{~m}$ around each site occupied between 15.24 and $83.07 \%$ of the superficies. Cornfields accounted for from 5.14 to $71.74 \%$. Non-crop areas occupied between 0.16 and $62.50 \%$ of the superficies and landscape diversity varied from 1.10 to 2.33 .

In 2006 , the natural enemy abundance was positively associated with the area under pasture within $500 \mathrm{~m}$ and the model accounted for $21.58 \%$ of the variation (adjusted $\mathrm{R}^{2}, \mathrm{p}=0.009$, Table 2 ). In 2007, natural enemy abundance was positively associated with the area under other crops than corn within 200 and $500 \mathrm{~m}$ and negatively associated with the area under fodder crops within $500 \mathrm{~m}$ (Table 2). This model accounted for $11.33 \%$ of the variation (adjusted $\mathrm{R}^{2}, \mathrm{p}<0.001$ ) and landscape descriptors within $500 \mathrm{~m}$ accounted for a greater part of the variation (Table 2). Area under crops other than corn appeared to be positively associated with landscape diversity at both scales (correlation coefficient 0.38 at $200 \mathrm{~m}$ and 0.45 at $500 \mathrm{~m}$ ).

In 2006, natural enemy richness was not influenced by landscape structure since no variable in the model had a significant effect. However, there was a tendency for the area under corn within $500 \mathrm{~m}$ to have a negative association with richness ( $p=0.055$, regression slope -0.335 ). Area under corn within $500 \mathrm{~m}$ appeared to be negatively associated with the area under crops other than corn and landscape diversity (correlation coefficient respectively -0.66 and -0.58 ). These correlations may explain why no landscape variable in the 2006 analysis was significant. In 2007 , natural enemy richness was positively associated with the area under water within 200 and $500 \mathrm{~m}$, landscape diversity within $200 \mathrm{~m}$ and area under crops other than corn within $500 \mathrm{~m}$ (Table 2). This model accounted for $9.32 \%$ of the variation (adjusted $R^{2}, p=0.008$ ) and descriptors at $500 \mathrm{~m}$ accounted for a greater part of the variation (Table 2). As mentioned previously, area under crops other than corn within $500 \mathrm{~m}$ was positively associated with landscape diversity. Area under water within $200 \mathrm{~m}$ was positively associated with other non-crop areas, which included area under fallow and riparian vegetation (correlation coefficient 0.54), whereas area under water within $500 \mathrm{~m}$ was slightly positively associated with non-crop patchiness (correlation coefficient 0.28). Landscape diversity was positively associated with landscape patchiness (correlation coefficient 0.44 ).

Table 2 Influence of landscape structure on natural enemy abundance and richness in 2006 and 2007. Each model is the result of a variable selection of elements in each landscape matrix followed by a variation partitioning between the landscape descriptors at 200 and $500 \mathrm{~m}$, using the significant variables within each set.

aThe number is the total number of milkweed plants surveyed

bThe percentage presented is the global contribution (adjusted $\mathrm{R}^{2}$ )

\begin{tabular}{|c|c|c|c|c|c|c|}
\hline \multirow{2}{*}{ Landscape descriptors } & \multicolumn{3}{|c|}{ Variable selection } & \multirow[t]{2}{*}{ Regression slope } & \multicolumn{2}{|c|}{ Model $^{\mathrm{b}}$} \\
\hline & $\mathrm{n}^{\mathrm{a}}$ & $\mathrm{F}$ & $\mathrm{p}$ & & $\%$ & $\mathrm{p}$ \\
\hline Abundance 2006 & 31 & & & & 21.58 & 0.009 \\
\hline Pasture $500 \mathrm{~m}$ & & 9.257 & 0.010 & 0.334 & & \\
\hline Abundance 2007 & 148 & & & & 11.33 & $p<0.001$ \\
\hline $200 \mathrm{~m}$ & & & & & 2.21 & 0.044 \\
\hline Other crops & & 4.314 & 0.036 & 0.043 & & \\
\hline $500 \mathrm{~m}$ & & & & & 11.74 & $p<0.001$ \\
\hline Other crops & & 14.541 & 0.001 & 0.068 & & \\
\hline Fodder crop & & 6.476 & 0.012 & -0.051 & & \\
\hline Richness 2006 & 31 & n.s. & n.s. & n.s. & n.s. & n.s. \\
\hline Richness 2007 & 148 & & & & 9.32 & 0.008 \\
\hline $200 \mathrm{~m}$ & & & & & 5.27 & 0.029 \\
\hline Water & & 6.062 & 0.023 & 0.1397 & & \\
\hline Landscape diversity & & 3.998 & 0.044 & 0.1114 & & \\
\hline $500 \mathrm{~m}$ & & & & & 10.08 & 0.005 \\
\hline Other crops & & 9.255 & 0.003 & 0.1933 & & \\
\hline Water & & 8.731 & 0.009 & 0.1621 & & \\
\hline
\end{tabular}




\section{Species composition}

In 2006, the effect of landscape structure on the natural enemy species composition accounted for $6.41 \%$ of the variation $(p=0.040)$ and the variation accounted for was the same for the landscape descriptors at both $200 \mathrm{~m}$ and $500 \mathrm{~m}$ (Table 3). Landscape diversity within $200 \mathrm{~m}$ had the highest positive association with $P$. quatuordecimpunctata (regression slope 0.1764, Fig. 2c) and highest negative association with cecidomyiid larvae (regression slope -0.1282), with intermediate positive or negative associations with other natural enemies. In contrast, the area under corn within $500 \mathrm{~m}$ had the highest positive association with cecidomyiid larvae (regression slope
0.1577, Fig. 2a) and highest negative association with $H$. axyridis (regression slope -0.1347 ).

In 2007 , the effect of landscape structure on the natural enemy species composition accounted for $8.81 \%$ of the variation $(\mathrm{p}<0.001)$ and landscape descriptors at $500 \mathrm{~m}$ had a greater contribution than descriptors at $200 \mathrm{~m}$ (Table 3). Area under crops other than corn within $200 \mathrm{~m}$ had the highest positive association with C. septempunctata (regression slope 0.1302, Fig. 2b) and the highest negative association with C. maculata (regression slope -0.0746). Area under crops other than corn within $500 \mathrm{~m}$ had the highest positive association with C. septempunctata (regression slope 0.1245 , Fig. 2b), slightly lower association with $H$. axyridis (regression slope 0.1121 ) and highest

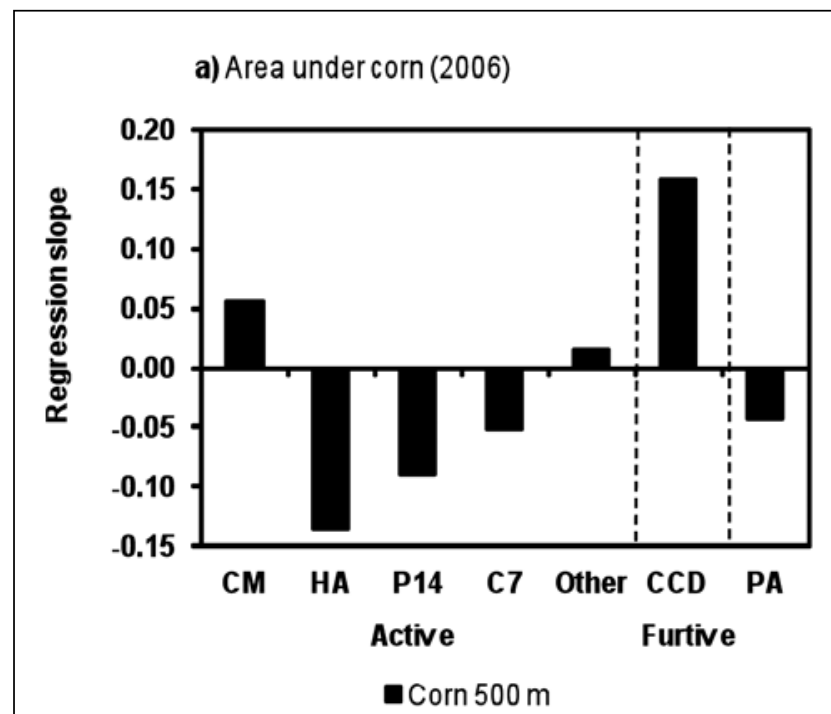

c) Landscape diversity (2006)

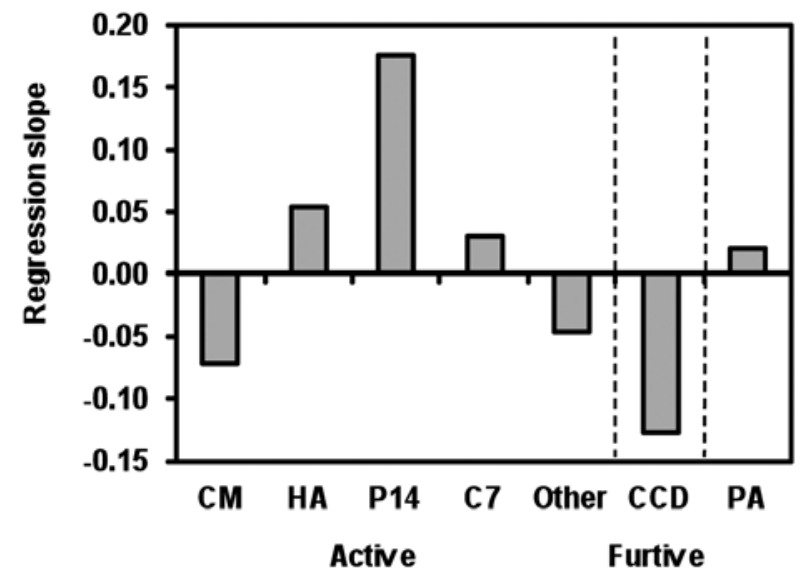

口Landscape diversity $200 \mathrm{~m}$ b) Area under crops other than corn (2007)

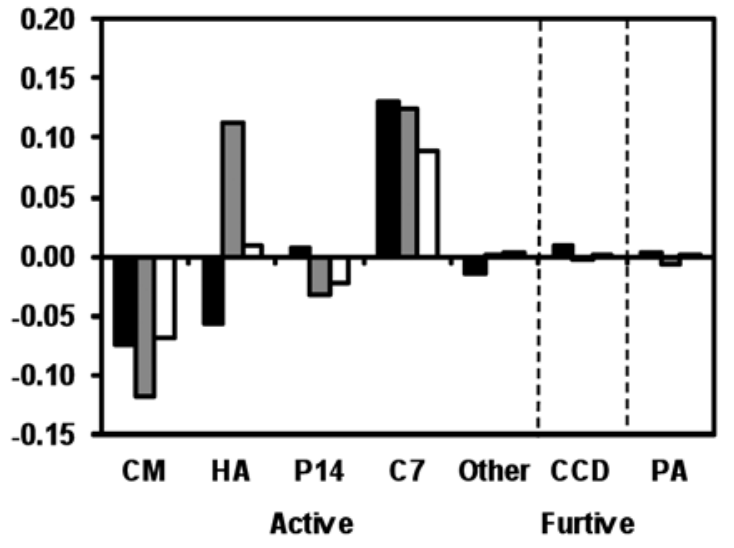

- Other crops $200 \mathrm{~m}$ 口Other crops $500 \mathrm{~m}$ 口Fodder crop $500 \mathrm{~m}$

d) Non-crops areas (2007)

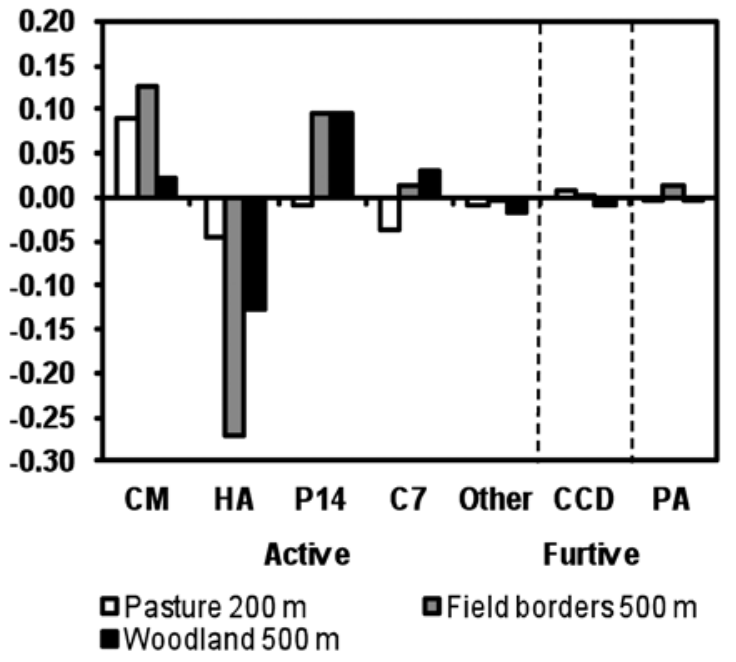

Fig. 2 Influence of landscape structure on the functional groups of aphidophagous natural enemies, active-searching predators, furtive predators and parasitoids: a) area under corn (2006), b) area under crops other than corn (2007), c) landscape diversity (2006) and d) non-crop areas (2007). Regression slopes were used to determine the direction of the association with each descriptor (positive or negative). Slope superior to $10 \%$ was considered to indicate a high association with natural enemies. Each histogram corresponds to the value of the regression slope for the selected landscape descriptor. $\mathrm{CM}=\mathrm{C}$. maculata, $\mathrm{HA}=\mathrm{H}$. axyridis, $\mathrm{P} 14=$ P. quatuordecimpunctata, $\mathrm{C7}=\mathrm{C}$. septempunctata, Other = Other active-searching predators (Chrysopidae, Hemerobiidae and Syrphidae), $C C D=$ Cecidomyiid larvae, PA = Parasitoid. Vertical dotted lines separate the functional groups: active-searching predators, furtive predators and parasitoids. 
negative association with $C$. maculata (regression slope -0.1183 ). Area under fodder crops within $500 \mathrm{~m}$ had the highest positive association with $C$. septempunctata (regression slope 0.0880 , Fig. $2 \mathrm{~b}$ ) and the highest negative association with $C$. maculata (regression slope -0.0683). Area under pasture within $200 \mathrm{~m}$ had the highest positive association with C. maculata (regression slope 0.0903, Fig. 2d) and the highest negative association with $H$. axyridis (regression slope -0.0461 ). Area under woodland within $500 \mathrm{~m}$ had the highest positive association with P. quatuordecimpunctata (regression slope 0.0964, Fig. 2d) and the highest negative association with $H$. axyridis (regression slope -0.1261). Finally, the area of field borders within $500 \mathrm{~m}$ had the highest positive association with C. maculata (regression slope 0.1271, Fig. 2d) and the highest negative association with $H$. axyridis (regression slope -0.2718).

Table 3 Influence of landscape structure on natural enemy species composition in 2006 and 2007. Each model is the result of a variable selection of elements in each landscape matrix followed by a variation partitioning between landscape descriptors at 200 and $500 \mathrm{~m}$, using the significant variables within each set.

aThe number is the total number of milkweed plants surveyed ${ }^{\text {b}}$ The percentage presented is the global contribution (adjusted $\mathrm{R}^{2}$ )

\begin{tabular}{|l|c|c|c|c|c|}
\hline \multirow{2}{*}{ Landscape descriptors } & \multicolumn{2}{|c|}{$\begin{array}{c}\text { Variable } \\
\text { selection }\end{array}$} & \multicolumn{4}{c|}{ Model $^{\text {b }}$} \\
\cline { 2 - 6 } & $\mathrm{n}^{\text {a }}$ & $\mathrm{F}$ & $\mathrm{p}$ & $\%$ & $\mathrm{p}$ \\
\hline $\mathbf{2 0 0 6}$ & $\mathbf{3 1}$ & & & $\mathbf{6 . 4 1}$ & $\mathbf{0 . 0 4 0}$ \\
\hline Landscape diversity 200 $\mathrm{m}$ & & 2.636 & 0.021 & 5.17 & 0.026 \\
\hline Corn $500 \mathrm{~m}$ & & 2.615 & 0.033 & 5.11 & 0.046 \\
\hline $\mathbf{2 0 0 7}$ & $\mathbf{1 4 2}$ & & & $\mathbf{8 . 8 1}$ & $<\mathbf{0 . 0 0 1}$ \\
\hline $200 \mathrm{~m}$ & & & & 3.93 & $<0.001$ \\
\hline Other crops & & 5.301 & 0.002 & & \\
\hline Pasture & & 2.410 & 0.032 & & \\
\hline $500 \mathrm{~m}$ & & & & 7.50 & $<0.001$ \\
\hline Other crops & & 4.212 & 0.007 & & \\
\hline Fodder crop & & 2.555 & 0.036 & & \\
\hline Woodland & & 3.503 & 0.012 & & \\
\hline Density of field borders & & 4.746 & 0.005 & & \\
\hline
\end{tabular}

\section{Discussion}

This study confirms that aphidophagous natural enemies are influenced by landscape structure. Furthermore, the effect of landscape structure varied greatly among the functional groups of aphidophagous natural enemies and among species within a specific functional group.

First, natural enemy abundance was positively associated with the area under non-crops (in particular, pasture) and area under crops other than corn, which is positively associated with landscape diversity. This confirms that it is important to conserve non-crop areas in agricultural landscapes, as mentioned in previous studies, because they may provide a source of natural enemies for controlling crop pests (Bianchi and van der Werf 2003; Gardiner et al. 2009b). Natural enemy richness was also positively associated with non-crop areas (area under water) and landscape diversity (landscape diversity per se and crops other than corn). Since landscape diversity is also associated with landscape patchiness, the results are in accordance with Elliott et al. (1998), who record that pasture and landscape patchiness are positively associated with natural enemy richness. In the Vacher creek watershed, cornfields are globally dominant even though there are several very different agricultural landscapes there: in the center of the watershed, there are bigger fields along with small patches of woodland and non-crop areas, whereas the eastern part is characterised by small areas of crops and non-crops and more woodland (Ruiz et al. 2008). The results indicate that when crops other than corn are cultivated they contribute to increase landscape diversity, thus increasing the abundance and richness of aphidophagous natural enemies. When the scale is taken into consideration, landscape descriptors at $500 \mathrm{~m}$ appeared more important for natural enemy abundance and richness than descriptors at $200 \mathrm{~m}$, which indicates that natural enemies are more affected by variables acting at a large scale. In other studies, parasitoids are affected by landscape structure at a similar scale $(500 \mathrm{~m}$, Thies et al. 2005) but Coccinellidae and Syrphidae at larger scales, i.e., in areas between $1500 \mathrm{~m}$ and $2000 \mathrm{~m}$ surrounding the focal field (Sarthou et al. 2005; Gardiner et al. 2009a,b).

There are important differences within and between the functional groups of aphidophagous natural enemies. Active-searching predators include natural enemies belonging to various families and species, which may be influenced by landscape structure in different ways as indicated by the results of this study. First, regarding the Coccinellidae, C. maculata, a native species in Canada, was highly positively associated with the density of field borders and area under pasture and to a less extent the area under corn, and negatively associated with the area under crops other than corn and landscape diversity. This means that this species is more abundant in less diversified landscapes dominated by non-crop areas (especially grassland) and to less extent cornfields. Other studies confirm this species positive association with non-crop areas (Elliott et al. 1998: woodland, pasture and conservation area; Elliott et al. 2002a: woodland) whereas one study records a negative association with pasture and grassland (Elliott et al. 2002a). Elliott et al. (1998) also report that the abundance of $C$. maculata is positively associated with landscape patchiness.

Interestingly, results for the exotic coccinellid species, H. axyridis, P. quatuordecimpunctata and C. septempunctata differ from those for C. maculata. These species were more abundant in diversified landscapes dominated by crops other than corn, with few non-crop areas. These results confirm the observations made by Gardiner et al. (2009a) in the Northeast USA, which indicate that native Coccinellidae (including C. maculata) were more abun- 
dant in less diversified landscapes dominated by grassland, whereas exotic Coccinellidae (including H. axyridis, P. quatuordecimpunctata and C. septempunctata) were more abundant in landscapes dominated by woodland. In the current study, the positive association of exotic species with the area under woodland was confirmed for P. quatuordecimpunctata and C. septempunctata, but not H. axyridis.

Harmonia axyridis was highly positively associated with the area under crops other than corn and negatively associated with the density of field borders and area under corn, woodland and pasture. This suggests that $H$. axyridis is more abundant in diversified landscapes dominated by cultivated fields, especially crops other than corn, with few non-crop areas. This result is in accordance with studies that found that $H$. axyridis is the dominant species in soybean crops in the USA (Gardiner et al. 2009a,b) and is also one of the most common coccinellids in soybean crops in Canada (Rutledge et al. 2004; Mignault et al. 2006; Lucas et al. 2007). Moreover, H. axyridis eats significantly more aphids than pollen in cornfields, suggesting some food specialization and that this species may respond to aphid densities (Lundgren et al. 2004). Thus, the high abundance of aphids in soybean fields in 2007 (Parent 2007) may explain why $H$. axyridis was more abundant in landscape dominated by crops other than corn. Interestingly, H. axyridis was almost the only aphidophagous natural enemy negatively associated with the density of field borders (the other was the "other active predators" group, but the association was very weak). Since $H$. axyridis is considered as an invasive species, conserving field borders may be to the advantage of other coccinellid species, particularly the native C. maculata.

The exotic Propylea quatuordecimpunctata was highly positively associated with landscape diversity and to a less extent the area under woodland and the density of field borders. This suggests that $P$. quatuordecimpunctata was more abundant in highly diversified landscapes dominated by non-crop areas, which seem to be a mix of the landscape effects on C. maculata and $\mathrm{H}$. axyridis. Coccinella septempunctata was highly positively associated with the area under crops other than corn and less so with the area under fodder crops. This suggests that $C$. septempunctata is more abundant in landscapes dominated by cultivated fields, especially crops other than corn. Coccinella septempunctata is also one of the most abundant coccinellids found in soybean fields in Canada, even if it is less abundant than H. axyridis or P. quatuordecimpunctata (Mignault et al. 2006; Lucas et al. 2007), so this may explain why this species is more abundant in landscapes dominated by crops other than corn, like $H$. axyridis. In the USA, C. septempunctata is also positively associated with wetland (Elliott et al. 2002b) and conservation areas (Elliott et al. 1998) and negatively associated with pasture and landscape patchiness, whereas with woodland the association is either positive or negative (Elliott et al. 1998). Overall, the effect of landscape structure on C. sep- tempunctata seems to vary a lot, which can be explained by its high mobility and the fact that this species feeds and reproduces in many habitats (Hodek and Michaud 2008). Globally, these results support the fact that these species of coccinellid are influenced in different ways by landscape structure and there are distinct differences in the ways the native and exotic species respond.

Other active-searching predators (i.e., Chrysopidae, Hemerobiidae and Syrphidae larvae) were less influenced by landscape structure than other natural enemies (regression slopes often approaching zero). Yet, the results suggest that active predators are more abundant in less diversified landscapes, which is not supported by other studies. However, in USA, the abundance of Chrysopidae is positively associated with conservation areas (Elliott et al. 2002b), pasture, woodland and landscape patchiness (Elliott et al. 1998). On the contrary, one study in Canada found that the abundance of Chrysopidae is negatively associated with the proximity of woodland (Mignon et al. 2003), which accords with the results of the present study with the exception of the very low negative association with woodland. Regarding the Syrphidae, one study in France found that the abundance of Episyrphus balteatus was positively associated with woodland geometry and the area of shrubby fallows (Sarthou et al. 2005). If more specimens of Chrysopidae, Hemerobiidae and Syrphidae had been observed, it may have been possible to determine the effect of landscape structure on each of these families. The pooled results for these active-searching predators indicate they had little association with landscape structure possibly because these predators individually have different associations.

In contrast, the furtive predators, i.e. cecidomyid larvae, had a strong positive association with the area under corn and a negative association with landscape diversity. This means that they are more abundant in a less diversified landscapes dominated by cornfields. So, they seem to be associated with the same landscape descriptors as C. maculata, except for the non-crop areas that appeared non-significant for cecidomyiid larvae. Conversely, furtive predators differ in their associations from the exotic Coccinellidae.

Finally, the influence of landscape structure on parasitoids was low but the results suggest that they were less abundant in landscapes dominated by cornfields, so they were more abundant in diversified landscapes. In other studies, aphid parasitoid abundance and aphid parasitism rate are positively related with non-crop areas (Roschewitz et al. 2005; Thies et al. 2005). In this study, the density of field borders was also positively associated with parasitoid abundance, which accords with previous results, but the regression slope is very low.

In summary, the active-searching predators belonging to the Coccinellidae and the furtive predators were the most influenced by landscape descriptors whereas other active predators (Chrysopidae, Hemerobiidae and Syrphidae) and parasitoids were only weakly affected. In 
addition, within the active-searching predator group, the native and exotic species of Coccinellidae respond differently to landscape structure. Finally, the furtive predators (i.e., cecidomyid larvae), were highly influenced by landscape structure similarly to the native species $C$. maculata but differently from the exotic Coccinellidae.

\section{Conclusion}

These results suggest that conserving non-crop areas and cultivating crops other than corn, thus increasing landscape diversity, would globally increase the abundance and diversity of aphidophagous natural enemies, therefore contributing to the conservative biological control of crop pests. Furthermore, the influence of landscape structure on the different functional groups of natural enemies and the different species within a specific functional group differ greatly. Therefore, before manipulating an agricultural landscape it is crucial to consider the objective: Is it increasing the whole abundance/ richness of the natural enemy guild, or increasing the abundance of one specific functional group or of one species?

\section{Acknowledgements}

We would like to thank the Fonds Québécois de la Recherche sur la Nature et les Technologies (FQRNT) for funding as well as the Ministère du Développement durable, de l'Environnement et des Parcs du Québec. Our thanks also go to Pedro Peres-Neto for help in statistical analyses. Finally, we would like to thank Nathalie Roullé, Karine Gauthier, Simon Paradis, Maryse Desrochers, Noémie Charest-Bourdon, Félix Bureau-Primeau, Dominique Dubreuil and Anik Pelletier-Leboeuf for their help with field work and the laboratory of biological control of UQAM.

\section{REFERENCES}

Bianchi FJJA, van der Werf W (2003) The effect of the area and configuration of hibernation sites on the control of aphids by Coccinella septempunctata (Coleoptera: Coccinellidae) in agricultural landscapes: a simulation study. Env Ent 32: 1290-1304.

Borcard D, Legendre P, Drapeau P (1992) Partialling out the spatial component of ecological variation. Ecology 73: 1045-1055.

Burgio G, Ferrari R, Boriani L, Pozzati M, van Lenteren J (2006) The role of ecological infrastructures on Coccinellidae (Coleoptera) and other predators in weedy field margins within northern Italy agroecosystems. B Insectol 59: 59-67.

Burgio G, Ferrari R, Pozzati M, Boriani L (2004) The role of ecological compensation areas on predator populations: an analysis on biodiversity and phenology of Coccinellidae (Coleoptera) on non-crop plants within hedgerows in Northern Italy. B Insectol 57: $1-10$.

Chambers RJ (1988) Syrphidae. In: Minks AK, Harrewijn P (eds) Aphids. Their biology, natural enemies and control. Elsevier, Amsterdam, The Netherlands, pp 259-270.
ColungaGarcia M, Gage SH, Landis DA (1997) Response of all assemblage of Coccinellidae (Coleoptera) to a diverse agricultural landscape. Env Ent 26: 797-804.

Cowgill SE, Sotherton NW, Wratten SD (1993) The selective use of floral resources by the hoverfly Episyrphus balteatus (Diptera: Syrphidae) on farmland. Ann Appl Biol 122: 223-231.

Dixon AFG (1958) The escape responses shown by certain aphids to the presence of the coccinellid Adalia decempunctata (L.). Trans R Ent Soc Lond 110: 319-334.

Dixon AFG (1959) An experimental study of the searching behaviour of the predatory coccinellid beetle Adalia decempunctata (L.). J Anim Ecol 28: 259-281.

Eilenberg J, Hajek A, Lomer C (2001) Suggestions for unifying the terminology in biological control. BioControl 46: 387-400.

Elliott NC, Kieckhefer RW, Beck DA (2002a) Effect of aphids and the surrounding landscape on the abundance of Coccinellidae in cornfields. Biol Control 24: 214-220.

Elliott NC, Kieckhefer RW, Lee JH, French BW (1998) Influence of within-field and landscape factors on aphid predator populations in wheat. Landscape Ecol 14: 239-252.

Elliott NC, Kieckhefer RW, Michels GJ, Giles KL (2002b) Predator abundance in alfalfa fields in relation to aphids, within-field vegetation, and landscape matrix. Env Ent 31: 253-260.

Ferran A, Dixon AFG (1993) Foraging behaviour of ladybird larvae (Coleoptera: Coccinellidae). Eur J Ent 90: 383-402.

Frazer BD (1988) Coccinellidae. In: Minks AK, Harrewijn P (eds) Aphids. Their biology, natural enemies and control. Elsevier, Amsterdam, The Netherlands, pp 231-247.

Frechette B, Larouche F, Lucas É (2008) Leucopis annulipes larvae (Diptera: Chamaemyiidae) use a furtive predation strategy within aphid colonies. Eur J Ent 105: 399-403.

Gardiner MM, Landis DA, Gratton C, DiFonzo CD, O’Neal M, Chacon JM, Wayo MT, Schmidt NP, Mueller EE, Heimpel GE (2009b) Landscape diversity enhances biological control of an introduced crop pest in the north-central USA. Ecol Appl 19: 143-154.

Gardiner MM, Landis DA, Gratton C, Schmidt N, O'Neal M, Mueller E, Chacon J, Heimpel GE, DiFonzo CD (2009a) Landscape composition influences patterns of native and exotic lady beetle abundance. Diversity Distrib 15: 554-564.

Grez AA, Prado E (2000) Effect of plant patch shape and surrounding vegetation on the dynamics of predatory coccinellids and their prey Brevicoryne brassicae (Hemiptera: Aphididae). Env Ent 29: 1244-1250.

Grez AA, Zaviezo T, Tischendorf L, Fahrig L (2004) A transient, positive effect of habitat fragmentation on insect population densities. Oecologia 141: 444-451.

Hagen KS (1962) Biology and ecology of predaceous Coccinellidae. Ann Rev Ent 7: 289-326.

Harmon JP, Losey JE, Ives AR (1998) The role of vision and color in the close proximity foraging behavior of four coccinellid species. Oecologia 115: 287-292.

Helms SE, Scott JC, Scott JM, Hunter D (2004) Effects of variation among plant species on the interaction between a herbivore and its parasitoid. Ecol Ent 29: 44-51.

Hodek I, Michaud JP (2008) Why is Coccinella septempunctata so successful? (A point-of-view). Eur J Ent 105: 1-12.

Landis DA, Wratten SD, Gurr GM (2000) Habitat management to conserve natural enemies of arthropod pests in agriculture. Ann Rev Ent 45: 175-201.

Lee JC, Andow DA, Heimpel GE (2006) Influence of floral resources on sugar feeding and nutrient dynamics of a parasitoid in the field. Ecol Ent 31: 470-480.

Legendre P, Gallagher E (2001) Ecologically meaningful transformations for ordination of species data. Oecologia 129: 271-280. 
Legendre P, Legendre L (1998) Numerical Ecology. Elsevier, Amsterdam.

Losey JE, Denno RF (1998) The escape response of pea aphids to foliar-foraging predators: factors affecting dropping behaviour. Ecol Ent 23: 53-61.

Lucas É (2005) Intraguild predation among aphidophagous predators. Eur J Ent 102: 351-363.

Lucas É, Brodeur J (1999) Oviposition site selection by the predatory midge Aphidoletes aphidimyza (Diptera: Cecidomyiidae). Env Ent 28: 622-627.

Lucas É, Brodeur J (2001) A fox in sheep's clothing: furtive predators benefit from the communal defense of their prey. Ecology 82: 3246-3250.

Lucas É, Vincent C, Labrie G, Chouinard G, Fournier F, Pelletier F, Bostanian N, Coderre D, Mignault MP, Lafontaine P (2007) The multicolored Asian ladybeetle Harmonia axyridis (Coleoptera: Coccinellidae) in Quebec agroecosystems ten years after its arrival. Eur J Ent 104: 737-743.

Lundgren JG, Razzak AA, Wiedenmann RN (2004) Population responses and food consumption by predators Coleomegilla maculata and Harmonia axyridis (Coleoptera: Coccinellidae) during anthesis in an Illinois cornfield. Env Ent 33: 958-963.

Maisonhaute JÉ, Peres-Neto P, Lucas É (2010) Influence of agronomic practices, local environment and landscape structure on predatory beetle assemblage. Agr Ecosyst Env 139: 500-507.

Marino PC, Landis DA, Hawkins BA (2006) Conserving parasitoid assemblages of North American pest Lepidoptera: Does biological control by native parasitoids depend on landscape complexity? Biol Control 37: 173-185.

Markkula M, Tiittanen K (1985) Biology of the midge Aphidoletes and its potential for biological control. In: Hussey NW, Scopes N (eds) Biological Pest Control: The Glasshouse experience. Cornell University Press, New York, USA, pp 74-81.

Marks RJ (1977) Laboratory studies of plant searching behaviour by Coccinella septempunctata L. larvae. Bull Ent Res 67: 235-241.

MathWorks (2000) MATLAB version 6.0.0.88 Release12. The MathWorks Inc, Natick, Massachusetts, USA.

Mignault MP, Roy M, Brodeur J (2006) Soybean aphid predators in Québec and the suitability of Aphis glycines as prey for three Coccinellidae. BioControl 51: 89-106.

Mignon J, Colignon P, Haubruge É, Francis F (2003) Effet des bordures de champs sur les populations de chrysopes [Neuroptera : Chrysopidae] en cultures maraîchères. Phytoprotection 84: 121-128.

New TR (1988) Neuroptera. In: Minks AK, Harrewijn P (eds) Aphids. Their biology, natural enemies and control. Elsevier, Amsterdam, The Netherlands, pp 249-257.

Obata S (1986) Mechanisms of prey finding in the aphidophagous ladybird beetle, Harmonia axyridis [Coleoptera: Coccinellidae]. Entomophaga 31: 303-311.

Parent C (2007) Puceron du soya: explosion des populations dans certaines régions. Bulletin Grandes cultures 21 (13 juillet). Réseau d'avertissement phytosanitaire. http://www.agrireseau .qc.ca/Rap/documents/a21gc07.pdf. Accessed 8 December 2010.
Peres-Neto PR, Legendre P, Dray S, Borcard D (2006) Variation partitioning of species data matrices: estimation and comparison of fractions. Ecology 87: 2614-2625.

Ramirez RA, Snyder WE (2009) Scared sick? Predator-pathogen facilitation enhances exploitation of a shared resource. Ecology 90: 2832-2839.

Rand TA, Tscharntke T (2007) Contrasting effects of natural habitat loss on generalist and specialist aphid natural enemies. Oikos 116: 1353-1362.

Roschewitz I, Hucker M, Tscharntke T, Thies C (2005) The influence of landscape context and farming practices on parasitism of cereal aphids. Agric Ecosyst Env 108: 218-227.

Ruiz J, Domon G, Lucas É, Côté MJ (2008) Vers des paysages multifonctionnels en zone d'intensification agricole : une recherche interdisciplinaire au Québec (Canada). Rev For Fr 5: 589-601.

Rutledge CE, O’Neil RJ, Fox TB, Landis DA (2004) Soybean aphid predators and their use in integrated pest management. Ann Ent Soc Am 97: 240-248.

Sarthou JP, Ouin A, Arrignon F, Barreau G, Bouyjou B (2005) Landscape parameters explain the distribution and abundance of Episyrphus balteatus (Diptera : Syrphidae). Eur J Ent 102: 539-545.

Schweiger O, Maelfait JP, Van Wingerden W, Hendrickx F, Billeter R, Speelmans M, Augenstein I, Aukema B, Aviron S, Bailey D, Bukacek R, Burel F, Diekotter T, Dirksen J, Frenzel M, Herzog F, Liira J, Roubalova M, Bugter R (2005) Quantifying the impact of environmental factors on arthropod communities in agricultural landscapes across organizational levels and spatial scales. J Appl Ecol 42: 1129-1139.

Sutherland JP, Sullivan MS, Poppy GM (2001) Distribution and abundance of aphidophagous hoverflies (Diptera: Syrphidae) in wildflower patches and field margin habitats. Agr Forest Ent 3: 57-64.

Thies C, Roschewitz I, Tscharntke T (2005) The landscape context of cereal aphid-parasitoid interactions. Proc R Soc B 272: 203-210.

Thorbek P, Topping CJ (2005) The influence of landscape diversity and heterogeneity on spatial dynamics of agrobiont linyphiid spiders: An individual-based model. BioControl 50: 1-33.

Vet LEM, Wäckers FL, Dicke M (1991) How to hunt for hiding hosts: the reliability-detectability problem in foraging parasitoids. Neth J Zool 41: 202-213.

Vinson SB (1998) The general host selection behavior of parasitoid hymenoptera and a comparison of initial strategies utilized by larvaphagous and oophagous species. Biol Control 11: 79-96.

Weibull AC, Östman Ö (2003) Species composition in agroecosystems: The effect of landscape, habitat, and farm management. Basic Appl Ecol 4: 349-361.

Yoshida T, Tanaka K (2005) Land-use diversity index: a new means of detecting diversity at landscape level. Landscape Ecol Eng 1: 201-206.

Zaviezo T, Grez AA, Estades CF, Pérez A (2006) Effects of habitat loss, habitat fragmentation, and isolation on the density, species richness, and distribution of ladybeetles in manipulated alfalfa landscapes. Ecol Ent 31: 646-656. 